\title{
Biosorption of 5G blue reactive dye using waste rice husk
}

\author{
Ismael Laurindo Costa Junior ${ }^{1+}\left(\mathbb{C}\right.$, Leandro Finger², Poliana Paula Quitaiski $\left.{ }^{(}\right)$, Samuel Mathias Neitzke ${ }^{1}$, Josue Victor \\ Besen ${ }^{1}$, Maike Krug Correa ${ }^{1}$, Juliana Bortoli Rodrigues Mees ${ }^{2}$ \\ ${ }^{1}$ Federal Technological University of Paraná, Campus Medianeira, Department of Chemistry, 4232 Brasil Av, Medianeira, Paraná, Brazil \\ 2 Federal Technological University of Paraná, Campus Medianeira, Department of Biological and Environmental Sciences, 4232 Brasil Av, \\ Medianeira, Paraná, Brazil \\ + Corresponding author: Ismael Laurindo Costa Junior, e-mail address: ismael@utfpr.edu.br
}

\section{ARTICLE INFO}

Article history:

Received: December 22, 2017

Accepted: October 06, 2018

Published: October 07, 2018
Keywords:

1. biosorbent

2. adsorption isotherms

3. 5G Reactive Dye

4. waste rice husk

ABSTRACT: In this study, the biosorption was used on the removal of $5 \mathrm{G}$ blue dye using rice husk residue. The influence of temperature and $\mathrm{pH}$ on the biomass pretreated with $\mathrm{H}_{3} \mathrm{PO}_{4}$ and $\mathrm{NH}_{4} \mathrm{Cl}$ was evaluated on the sorption capacity. The tests were conducted in batch with previous determination of point of zero charge (PZC). Analytical measurements were performed by UV-VIS spectroscopy. A major influence of $\mathrm{pH}$ and temperature on the biosorption capacity of the dye was observed. The highest removal was obtained for the condition of $\mathrm{pH} 4$ and temperature of $50{ }^{\circ} \mathrm{C}$. The time for the biomass-dye system to reach equilibrium was around $45 \mathrm{~min}$. Pseudo-first order kinetic model adequately represented experimental data and had a good correlation coefficient. In the equilibrium study, Langmuir isotherm best fitted the experimental data, with a maximum biosorption capacity of $3.84 \mathrm{mg} \mathrm{g}$ 1 . The use of rice husk as a biosorbent for the removal of reactive blue $5 \mathrm{G}$ dye can be considered promising for the abundance of this residue and the observed sorption capacity.

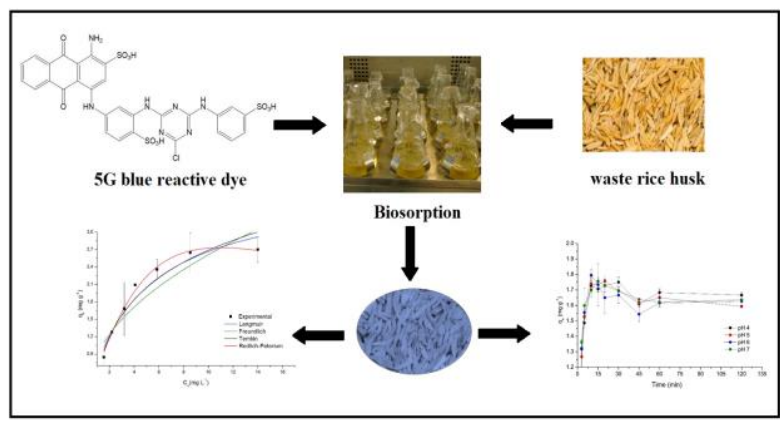

\section{Introduction}

In the industrial sector, several projects have been highlighted by the polluting potential, especially by the considerable amounts of residues rich in diverse types of substances highly harmful to water, air and soil. In this category, the textile industries are included as generators of environmental impacts and emitters of waste typically composed of the inputs used in its process, among which dyes, such as reactive blue dye $5 \mathrm{G}$ used on a large scale in the production of $\operatorname{denim}^{1,2}$.

Reactive dyes have been used on a growing scale by the textile industries due to their reactivity with fibers and color stability. The reactive dye molecule can be defined by the following structural systems: a chromophore system, responsible for the color phenomenon; a sulfonate group, responsible for the solubility and anionic character of the dye; and one or more reactive groups, which may form a covalent bond with the cellulose fibers by nucleophilic addition or substitution reaction ${ }^{3}$.

The increase of complexity and difficulty for the treatment of industrial effluents has led to the search of new methodologies for the removal of these wastes. The availability of innovative technologies and costs compatible with the need to reduce the environmental liabilities produced by industrial effluents is a fundamental task with repercussions in the short and medium term. As a measure to minimize the impacts caused by the 
discharge of effluents rich in specific pollutants such as dyes, companies have the option of using tertiary treatments, mainly physical and chemical. Currently, due to the cost and operational complexity, these systems have been neglected by alternative systems or the use of biomass through the processes of bioaccumulation and biosorption $^{4,5}$.

Biosorption is a passive process where the capture is carried out by inactive (dead) biomass. The capture of the contaminants by biomass occurs through physical-chemical interactions between the ions and the functional groups present on the biomass surface ${ }^{6}$.

A variety of biosorbents have been investigated such as banana peel, chitosan, orange peel, aquatic plants, cotton fibers, wood sawdust, sugarcane bagasse, corn cob, babassu coconut, among others $^{7,8}$. Aiming for efficiency, kinetic and equilibrium studies are required to better understand the mechanisms involved. The pseudofirst and pseudo-second order models are commonly applied for kinetic evaluation. For the biosorption equilibrium, isotherms are used to describe the experimental data accurately within a set of imposed conditions ${ }^{9}$. The commonly used models are Langmuir, Freundlich and Henry ${ }^{10,11}$.

Rice husk is a lignocellulosic compound formed, basically, by: i) cellulose (35\%), a semicrystalline polymer of anhydrocellulose, the units of which are interconnected via $\beta-1 \rightarrow 4$ bonds; (ii) hemicellulose $(13.1 \%)$, a heterogeneous polymer composed of the combination of three hexoses: $\beta$ $D$-glucose, $\beta$-D-mannose and $\beta$-D-galactose, three pentoses: $\quad \beta$-D-xylopyranose, $\quad \beta$-D arabinopyranose and $\beta$-D-galactouronic acid; and (iii) lignin (13.27\%), an amorphous aromatic polymer (methoxy-phenols forming a resin species in plants), consisting of two types of basic units: guaiac and syringyl ${ }^{12}$. This biomass is insoluble in water, has good chemical stability, high mechanical strength and has several functional groups in its structure such as $\mathrm{COOH},-\mathrm{OH}, \mathrm{SiOH}$, $\mathrm{CH}, \mathrm{C}=\mathrm{O}, \mathrm{C}=\mathrm{C}, \mathrm{CH}_{2}, \mathrm{CH}_{3}, \mathrm{CO}, \mathrm{Si}-\mathrm{O}-\mathrm{Si}$, Si-H, -O$\mathrm{CH}_{3}$, and therefore has potential to be a good adsorbent material ${ }^{13,14}$.

Biosorbents prepared with rice husk have been used in the adsorption of heavy metals, dyes and other organic compounds due to the large renewable production and the low cost for these adsorbents ${ }^{15-18}$. Previous researches reveal that rice husk can be used for removing ionic dyes from aqueous solutions and presented promising results.
This biomass presents high adsorption capacity, which is significantly increased when chemically modified $^{19-21}$.

This study investigated the removal of $5 \mathrm{G}$ blue reactive dye by means of biosorption using the rice husk residue as a biosorbent. Kinetic and equilibrium studies were performed to evaluate this biomass as a low-cost alternative, when compared to traditional physicochemical systems.

\section{Materials and methods}

\subsection{Reagents, solutions and analytical determinations}

All reagents used in this work were analytical grade, phosphoric acid 85\% (Merck), sodium hydroxide 97\% (Merck), hydrochloric acid 37\% (Merck), ammonium chloride P.A (VETEC) and sodium chloride P.A. (VETEC). Reactive dye 5G (TEXPAL) of commercial nature was used in powder form.

Solutions were prepared at the concentration of $1.0 \mathrm{~mol} \mathrm{~L}^{-1}$ for biomass treatments and for determination of the point of zero charge (PZC). From a stock solution of the $1000 \mathrm{mg} \mathrm{L}^{-1}$ dye and distilled water, working solutions were prepared with $20 \mathrm{mg} \mathrm{L}^{-1}$ used in the adsorption experiments.

The determination of the concentration of dye in the tests occurred by external calibration. For this, a six-point analytical curve was obtained using stock solution in the range from 0 to $50 \mathrm{mg} \mathrm{L}^{-1}$. Measurements were performed using a UV-VIS spectrophotometer (Perkin Elmer Lamba 45) at $589 \mathrm{~nm}$. The $\mathrm{pH}$ measurements were performed in bench potentiometer (Hanna 21).

\subsection{Preparation of the biosorbent}

Approximately $1.5 \mathrm{~kg}$ of rice husk were cleaned with distilled water by immersion for $24 \mathrm{~h}$. Subsequently, the material was drained and oven dried (Quimis) for $24 \mathrm{~h}$ at $60^{\circ} \mathrm{C}$. Subsequently the biomass was ground in a knife mill and divided into three equal portions. One of them was reserved as experimental blank. To evaluate the influence of chemical pretreatments, one of the portions of the dried rice husk was immersed in $1.0 \mathrm{~mol} \mathrm{~L}^{-1} \mathrm{H}_{3} \mathrm{PO}_{4}$, and the other was immersed in $1.0 \mathrm{~mol} \mathrm{~L}^{-1} \mathrm{NH}_{4} \mathrm{Cl}$ for $24 \mathrm{~h}$. After rinsing again with distilled water, they were again dried in an oven and packed in sealed containers. 


\subsection{Point of zero charge (PZC)}

The adsorption processes are strongly dependent on the $\mathrm{pH}$, which affects the surface charge of the adsorbent, the degree of ionization and the adsorbate species. The $\mathrm{pH}_{\mathrm{PCZ}}$ allows to predict the charge on the surface of the adsorbent as a function of $\mathrm{pH}$. For the determination of the $\mathrm{pH}_{\mathrm{PCZ}}$, samples composed of $0.5 \mathrm{~g}$ of rice husk were placed in Erlenmeyer flasks with $50 \mathrm{~mL}$ of $\mathrm{NaCl} 0.1 \mathrm{~mol} \mathrm{~L}^{-1}$ solution and adjusted $\mathrm{pH} 2$ to 12 with $\mathrm{NaOH}$ and $\mathrm{HCl} 0.1 \mathrm{~mol} \mathrm{~L}^{-1}$. The plastic film sealed bottles were kept under constant stirring $(120 \mathrm{rpm})$ in a shaker incubater (Lactea brand, model LAC-2000) at $25^{\circ} \mathrm{C}$. The $\mathrm{pH}$ was measured at intervals of $1 \mathrm{~h}$ until constant values were obtained. Stirring was continued for $24 \mathrm{~h}$ to ensure equilibrium of the solutions. The values were presented as a plot of $\triangle \mathrm{pH} \times$ initial $\mathrm{pH}$, and the $\mathrm{PCZ}$ value defined as the one that intercepts the $\mathrm{x}$-axis $(\Delta \mathrm{pH}=0)^{22}$.

\subsection{Biosorption Study}

For the $\mathrm{pH}$ effect evaluation, two values above and two below of the PZC were chosen. To study the temperature, tests were performed at 40 and $50{ }^{\circ} \mathrm{C}$, in addition to the ambient temperature $\left(25^{\circ} \mathrm{C}\right)$. The assays were carried out in duplicate in a $125 \mathrm{~mL}$ Erlenmeyer flask, kept under shaking at $120 \mathrm{rpm}$ in a shaker incubator. $0.5 \mathrm{~g}$ of biosorbent and $50 \mathrm{~mL}$ of dye solution $\left(20.0 \mathrm{mg} \mathrm{L}^{-1}\right)$ were added to each flask for kinetic test and at concentrations of 1.0, 5.0, 10.0, 15.0, 20.0, 25.0, $30.0,35.0$ and $40.0 \mathrm{mg} \mathrm{L}^{-1}$ for isotherm equilibrium test. After $4 \mathrm{~h}$, the biosorbent was removed by filtration and the dye concentrations were measured by using the spectrophotometer mentioned before.

The concentration of the dye in the adsorbent $\left(q_{e}\right)$, in $\mathrm{mg} \mathrm{g}^{-1}$, was calculated by Equation 1 .

$q_{e}=V \cdot \frac{\left(C_{0}-C_{e}\right)}{m}$

where $V$ is the volume of the solution (L), $C_{0}$ is the initial concentration of the solution $\left(\mathrm{mg} \mathrm{L}^{-1}\right), C_{e}$ is the concentration of the final test solution (mg L $\mathrm{L}^{-1}$ ). The dye concentration at equilibrium $\left(q_{e}\right)$ was determined by the inspection of the graph time $q_{e}(t)$ versus $(t)$, at the instant the removal was constant.

The equilibrium kinetic data were fitted to the pseudo-first order models (Eq. 2), pseudo-second order (Eq. 3) and the intraparticle diffusion model derived from Fick's law assuming that diffusion of the liquid film surrounding the adsorbent is negligible and intraparticle diffusion is the ratedetermining step of the adsorption process (Eq. 4) $)^{23-25}$.

$$
\begin{aligned}
& q(t)=q_{e}\left(1-e^{-k_{1} t}\right) \\
& q(t)=\frac{\left(q_{e}\right)^{2} k_{2} t}{\left(q_{e} k_{2} t\right)+1} \\
& q(t)=k_{3} t^{\frac{1}{2}}+C
\end{aligned}
$$

where $q_{e}$ and $q(t)$ are the equilibrium adsorption and the adsorption capacity at the time $t$, respectively, in $\mathrm{mg} \mathrm{g}^{-1} ; \mathrm{t}$ is the time in $\min ; C$ suggests the thickness of the boundary layer effect $\left(\mathrm{mg} \mathrm{g}^{-1}\right) ; k_{1}\left(\mathrm{~min}^{-1}\right), k_{2}\left(\mathrm{~g} \mathrm{mg}^{-1} \mathrm{~min}^{-1}\right)$ and $k_{3}$ $\left(\mathrm{g} \mathrm{mg}^{-1} \mathrm{~min}^{-1 / 2}\right.$ ) are the constants corresponding to the pseudo-first, pseudo second order and intraparticle diffusion models, respectively.

To describe the adsorption equilibrium, the adsorption isotherms models were adjusted to experimental data. Langmuir model hypothesizes that adsorption occurs in a monolayer manner and that all active sites are evenly distributed on the adsorbent and are available at the same energy "cost". These facts are important for the description of the interaction adsorbent-adsorbate (Eq. 5).

$q_{e}=\frac{q_{m} \cdot b \cdot C_{e}}{1+b \cdot C_{e}}$

where $q_{m}$ is the adsorption capacity of the studied material $\left(\mathrm{mg} \mathrm{g}^{-1}\right)$; and $b$ is the constant that measures the adsorbent-adsorbate affinity related to adsorption-free energy ${ }^{26,27}$.

The Freundlich model (Eq. 6) considers the heterogeneous solid and the exponential distribution to characterize the diverse types of adsorption sites, with different adsorptive energies $^{28}$.

$q_{e}=k_{L} \cdot C_{e}^{1 / n}$

where $k_{L}$ and $n$ are empirical constants ${ }^{29}$ and can be related to the changes in the adsorbed concentration with the changes in the solute concentration.

The Temkin model (Eq. 7) considers the effects 
of the indirect interactions between the adsorbate molecules and the decrease of the heat of adsorption with the increase of the rate of removal $^{30}$.

$q_{e}=B \cdot \ln k_{T} C_{e}$

where $B$ is the Temkin constant relating the heat of adsorption to the total number of sites $\left(\mathrm{mg} \mathrm{g}^{-1}\right)$ and $k_{T}$ is the Temkin constant $\left(\mathrm{L} \mathrm{mg}^{-1}\right)$.

The Redlich-Peterson model (Eq. 8) is used to represent equilibrium of adsorption over a wide range of concentrations and may be applied in homogeneous and heterogeneous systems, due to its versatility ${ }^{31}$.

$q_{e}=\frac{k_{R} \cdot C_{e}}{1+a_{R} \cdot C_{e}^{\beta}}$

where $k_{R}$ and $a_{R}$ are the Redlich-Peterson constants $\left(\mathrm{L} \mathrm{mg}^{-1}\right)$ and $\beta$ is the exponent with values from 0 to 1 . The parameters of the models were obtained from non-linear regression using
Origin $8.5^{\circledR}$ and the regression was assessed by ANOVA at the $95 \%$ level of significance.

\section{Results and discussion}

\subsection{Point of zero charge ( $\left.p H_{P Z C}\right), p H$ and temperature effect}

Figure 1 shows the variation of $\mathrm{pH}$ as a function of the initial $\mathrm{pH}$ for the three adsorbents: untreated, treated with $\mathrm{H}_{3} \mathrm{PO}_{4}$ and treated with $\mathrm{NH}_{4} \mathrm{Cl}$. The $\mathrm{pH}$ at the point of zero charge was approximately 5.0 for the natural rice rusk, 2.5 for the treatment with $\mathrm{H}_{3} \mathrm{PO}_{4}$ and 5.0 for treatment with $\mathrm{NH}_{4} \mathrm{Cl}$. Below these values the solid presents a positive surface charge favoring the adsorption of anions. Then, it is expected better adsorption on the studied biomass at $\mathrm{pHs}$ below $\mathrm{pH}_{\mathrm{PCZ}}$ due to the anionic characteristic of $5 \mathrm{G}$ blue reactive dye in aqueous solution.

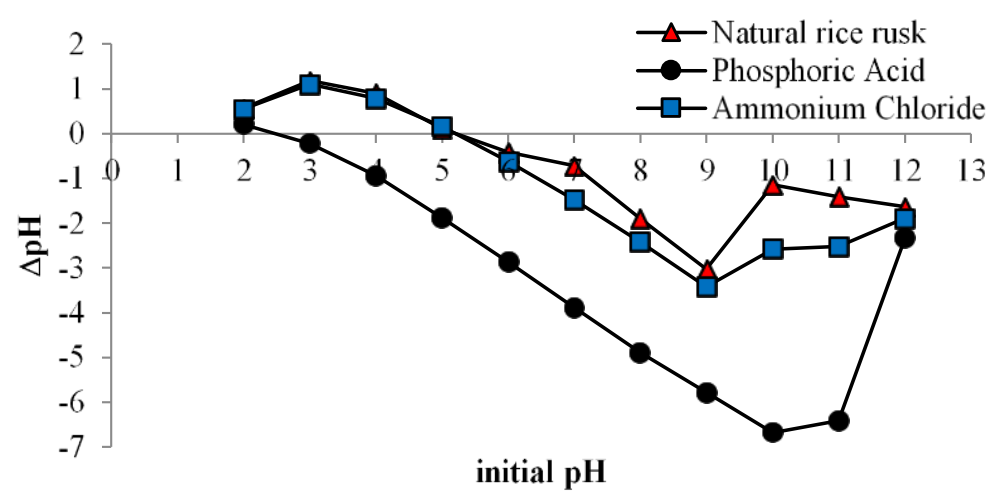

Figure 1. $\mathrm{pH}_{\mathrm{PCZ}}$ values for biosorbent rice husk natural and treated with $\mathrm{H}_{3} \mathrm{PO}_{4}$ and $\mathrm{NH}_{4} \mathrm{Cl}$.

Considering the value of the $\mathrm{pH}_{\mathrm{PCZ}}$, the objective was to determine the $\mathrm{pH}$ range where the biosorbent adsorb more dye. Figure 2 presents the quantity of adsorbed dye (per adsorbent unit mass) as a function of time, at different $\mathrm{pH}$ conditions and different adsorbents. 

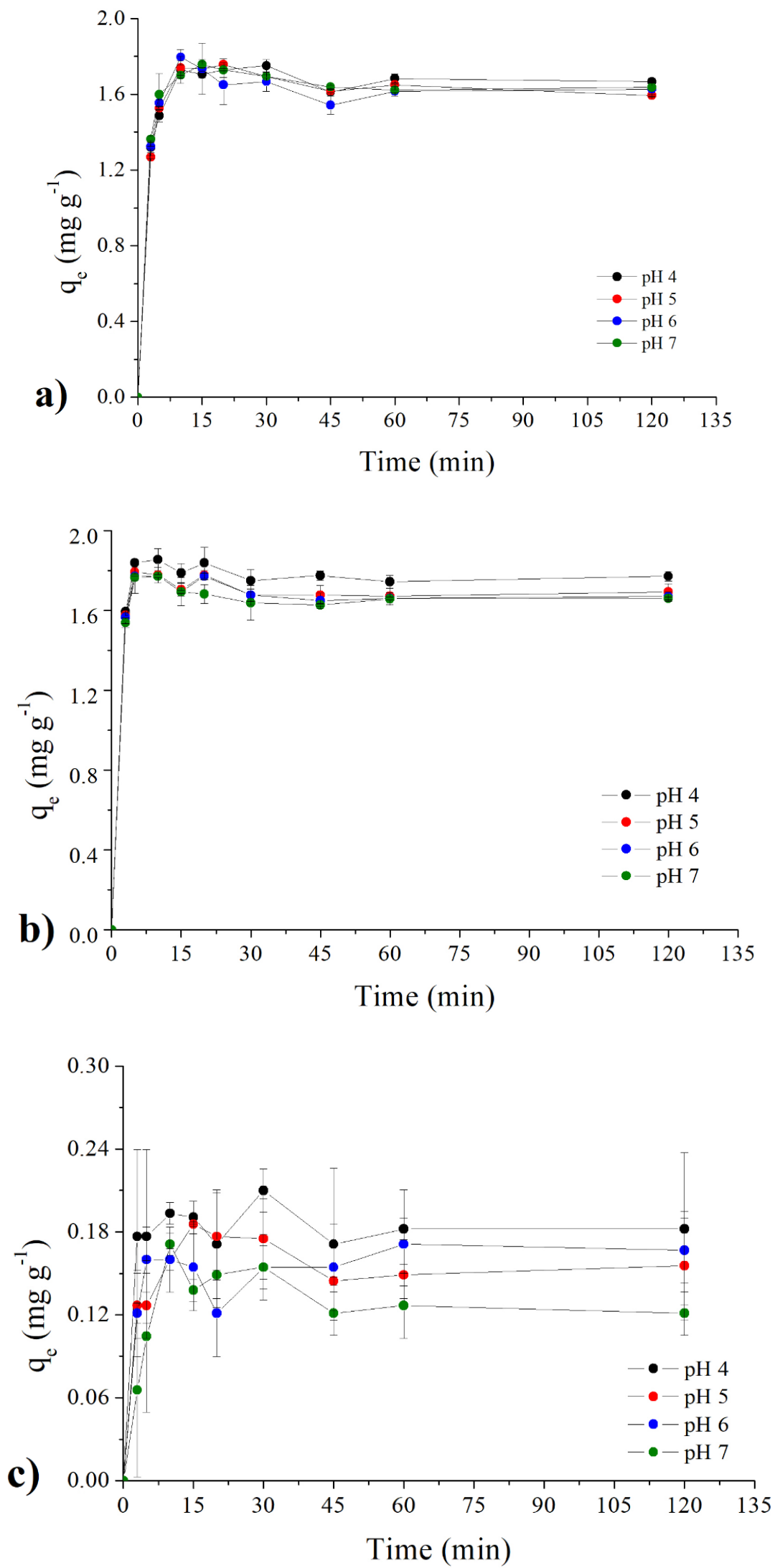

Figure 2. Influence of $\mathrm{pH}$ on biosorption $\left(q_{e}\right)$ at $25^{\circ} \mathrm{C}$. a) natural rice rusk, b) $\mathrm{H}_{3} \mathrm{PO}_{4}$ and c) $\mathrm{NH}_{4} \mathrm{Cl}$. 
It was observed that the biosorption of $5 \mathrm{G}$ Blue dye in solution by the rice hull is $\mathrm{pH}$ dependent. It was found that at $\mathrm{pH} 4$ the natural biomass removed $81.3 \%$ of the dye, already for $\mathrm{pH} 5$ it was $79.7 \%$, for $\mathrm{pH} 6$ it was $81.3 \%$ and $\mathrm{pH} 7$ was $82.8 \%$. In the pre-treatments the lower $\mathrm{pHs}$ were more efficient, removing $88.6 \%$ of the dye by the biomass pretreated with phosphoric acid and $9.1 \%$ with ammonium chloride. Considering the time of 120 min the values of $q_{e}$ were calculated for the studied $\mathrm{pH}$ values. These values are set forth in Table 1.

Table 1. Adsorption capacity of the study material $\left(\mathrm{mg} \mathrm{g}^{-1}\right)$ at time $120 \mathrm{~min}$ for differentpH values at $25{ }^{\circ} \mathrm{C}$.

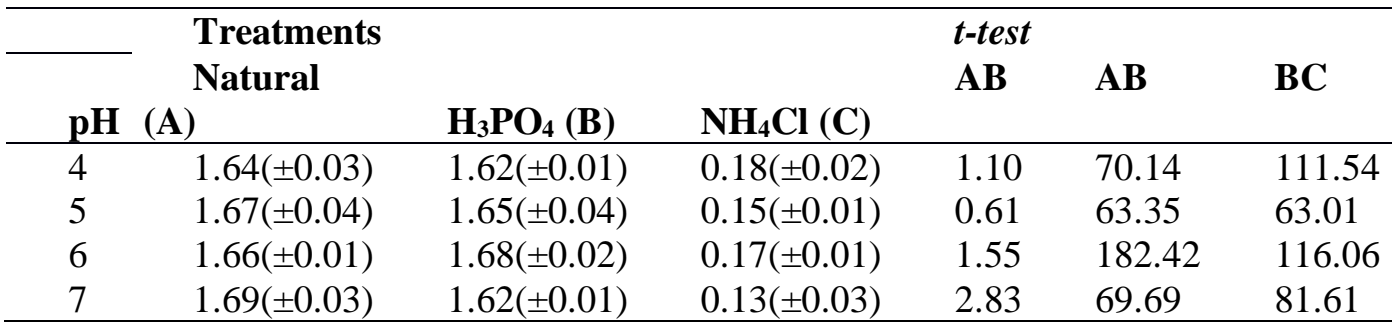

$\mathrm{t}_{\text {critical }}(\mathrm{n}=3 ; \mathrm{p}=0.05)=2.92$

For the comparison of the sorption capacity $\left(q_{e}\right)$ between the treatments at each $\mathrm{pH}$ evaluated, the $\mathrm{t}-$ test was applied at a significance level of $95 \%$ (Table 1). Considering the degrees of freedom equal to 3 , the critical value corresponds to $\mathrm{t}_{(3 ; 0.05)}=2.92$. All comparisons between the natural biosorbent and the $\mathrm{H}_{3} \mathrm{PO}_{4}(\mathrm{AB})$ treatment were considered statistically the same, since $t_{\text {critical }}>t_{\text {calculated. }}$ However, for the biomass prepared with $\mathrm{NH}_{4} \mathrm{Cl}$, sorption capacity was different from the other treatments (AC and $\mathrm{BC}$ ) because $t_{\text {critical }}<t_{\text {calculate }}$. Considering the lower values of $q_{e}$ it can be considered that the application of $\mathrm{NH}_{4} \mathrm{Cl}$ reduced the potential and sorption of the biomass studied and that the application of $\mathrm{H}_{3} \mathrm{PO}_{4}$ did not promote a statistically significant increase when compared to the natural biomass (Figure 2).
The $\mathrm{pH}$ can also affect the structural stability of the $5 \mathrm{G}$ blue reactive dye because, under an acidic condition, the dye molecule can be deprotonated within the solution, resulting in a polar molecule with a high negative charge density. Therefore, the electrostatic repulsion between the adsorbent site and the negatively charged dye ions was reduced at low $\mathrm{pH}$. Consequently, positively charged functional groups could exert a strong electrostatic attraction on anionic dye molecules ${ }^{32,33}$.

An evaluation of the effect of the temperature considers a dye removal for each treatment at temperatures of 25,40 and $50{ }^{\circ} \mathrm{C}$. Figure 3 shows the experimental data of amount of dye adsorbed $\left(q_{e}\right)$ versus time for each temperature studied at $\mathrm{pH} 4$.

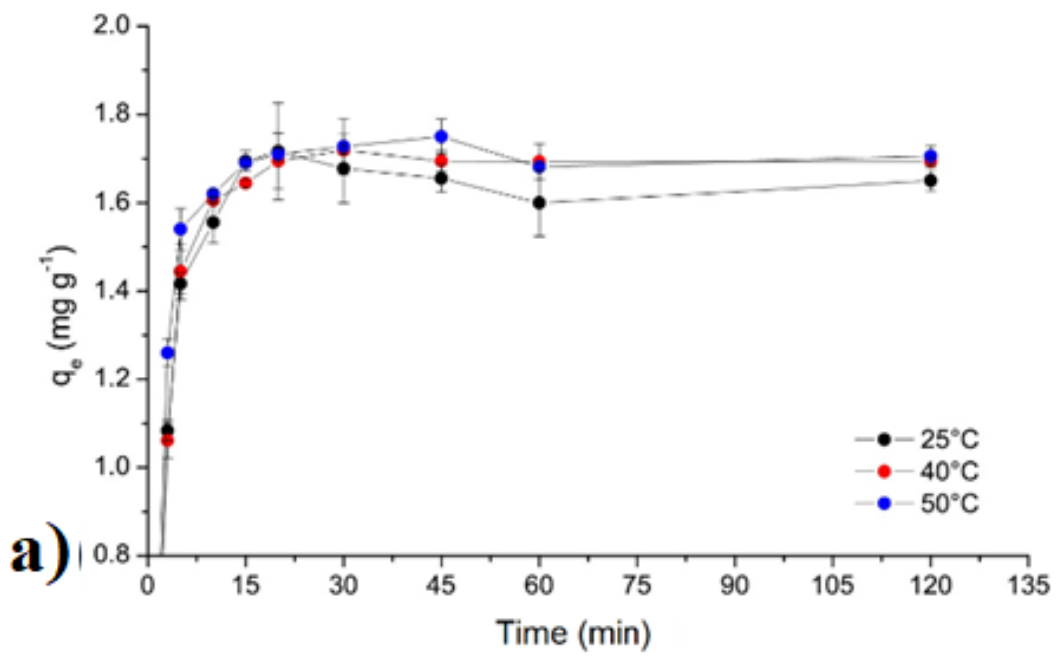



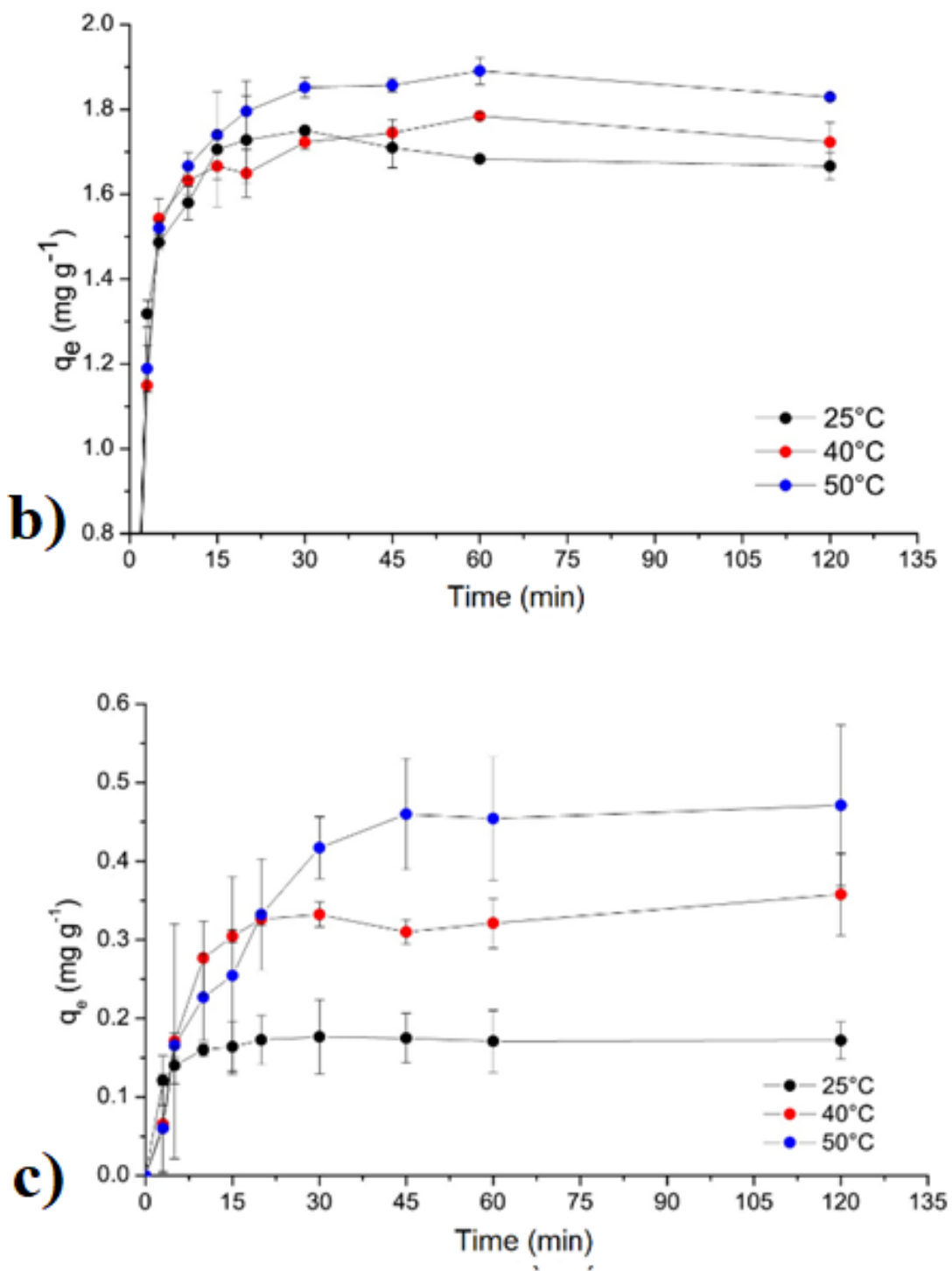

Figure 3. Influence of temperature on biosorption (qe) at $\mathrm{pH} 4$ : a) natural rice rusk, b) $\mathrm{H}_{3} \mathrm{PO}_{4}$ and c) $\mathrm{NH}_{4} \mathrm{Cl}$.

The temperature significantly influences the kinetic energy of the molecules and interferes on the attraction and repulsion forces between the adsorbate and the adsorbent ${ }^{33}$. In the range of temperature and conditions studied, an increase in the adsorbed amount was observed as the temperature increases, with $50{ }^{\circ} \mathrm{C}$ being the one that presented the best results. The biomass pretreated with $\mathrm{H}_{3} \mathrm{PO}_{4}$ at $50{ }^{\circ} \mathrm{C}$ showed the best dye removal, $91.5 \%$. It was observed that an increase in temperature favorably influenced the ability of the $5 \mathrm{G}$ Blue dye to be removed by the rice husk biomass.

This behavior could be explained by factors such as an increased in mobility of the molecules present in the solution (increased kinetic energy caused by the temperature rise), increased diffusion of adsorbate on the surface of the adsorbent, and dilation of the pores of the adsorbent ${ }^{34}$.

\subsection{Biosorption kinetic}

Figure 4 shows the quantity of adsorbed dye per unit mass of adsorbent as a function of time, at $\mathrm{pH}$ 4 and $50{ }^{\circ} \mathrm{C}$, for different pretreatments. The experimental data were adjusted to the models of pseudo-first order, pseudo-second order and intraparticle diffusion. The equilibrium time was about 20 min for in natura rice husk and about 35 min for both pretreated adsorbents.

Table 2 shows the fitted parameters and the determined coefficients for these experiments. 

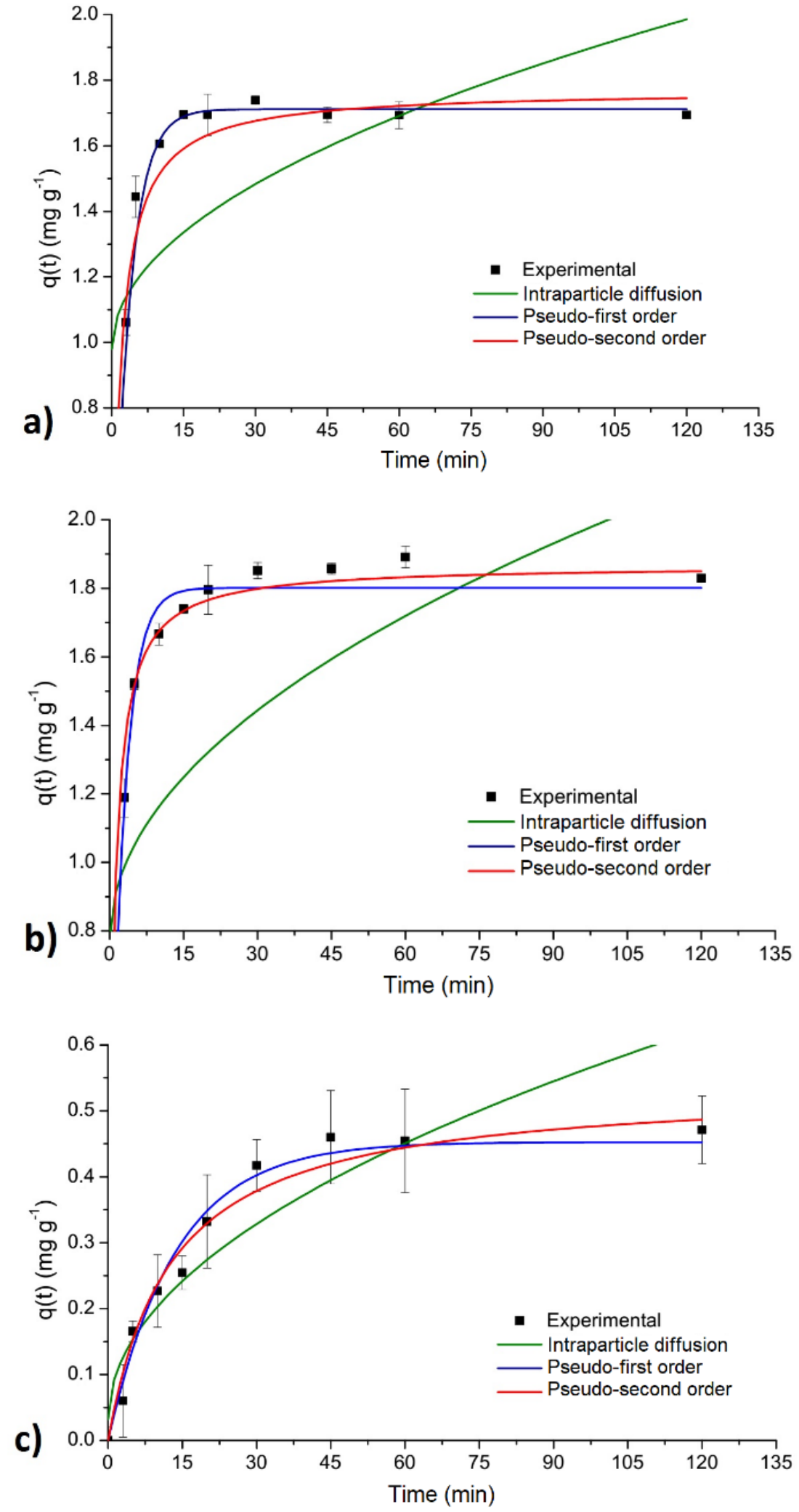

Figure 4. Experimental data and fit to intraparticle diffusion, pseudo-first and pseudo-second order models for the temperature of $50{ }^{\circ} \mathrm{C}$ and $\mathrm{pH}$ 4: a) natural rice rusk, b) $\mathrm{H}_{3} \mathrm{PO}_{4}$ and c) $\mathrm{NH}_{4} \mathrm{Cl}$. 
Table 2. Parameters of the adsorption kinetic models of the $5 \mathrm{G}$ blue dye by the biomass with different pretreatments for the conditions of $\mathrm{pH} 4$ and temperature of $50{ }^{\circ} \mathrm{C}$.

\begin{tabular}{|c|c|c|c|c|c|c|c|c|c|}
\hline & \multicolumn{3}{|c|}{ Pseudo-first order } & \multicolumn{3}{|c|}{ Pseudo-second order } & \multicolumn{3}{|c|}{ Intraparticle diffusion } \\
\hline Tratament & $\boldsymbol{q}_{e}^{\mathrm{a}}$ & $k_{l}^{\mathbf{b}}$ & $R^{2}$ & $q_{e}{ }^{\mathrm{a}}$ & $k_{2}^{c}$ & $R^{2}$ & $C$ & $k_{3}{ }^{\mathrm{d}}$ & $R^{2}$ \\
\hline \multirow{3}{*}{ Natural } & 1.71 & 0.29 & & 1.77 & 0.34 & & 0.98 & 0.09 & \\
\hline & $( \pm 0.01)$ & $( \pm 0.02)$ & 0.99 & $( \pm 0.01)$ & $( \pm 0.02)$ & 0.95 & $( \pm 0.28)$ & $( \pm 0.04)$ & 0.27 \\
\hline & 1.80 & 0.35 & & 1.87 & 0.47 & & 0.78 & 0.12 & \\
\hline \multirow[t]{2}{*}{$\mathrm{H}_{3} \mathrm{PO}_{4}$} & $( \pm 0.02)$ & $( \pm 0.03)$ & 0.99 & $( \pm 0.01)$ & $( \pm 0.05)$ & 0.99 & $( \pm 0.28)$ & $( \pm 0.04)$ & 0.44 \\
\hline & 0.45 & 0.07 & & 0.54 & 0.15 & & 0.03 & 0.05 & \\
\hline $\mathrm{NH}_{4} \mathrm{Cl}$ & $( \pm 0.03)$ & $( \pm 0.01)$ & 0.96 & $( \pm 0.04)$ & $( \pm 0.03)$ & 0.97 & $( \pm 0.02)$ & $( \pm 0.01)$ & 0.88 \\
\hline
\end{tabular}

Determination coefficients $\left(R^{2}\right)$ were obtained between 0.27 and 0.99 , indicating that some models do not represent satisfactory experimental data (Table 1). The best fit was observed for the pseudo-first order model, being suitable for all pretreatments. The pseudo-second order model was only suitable for the treatment with phosphoric acid. The intraparticle diffusion model presented a low correlation coefficient for all adsorption processes. Even though the correlation coefficient for the intraparticle diffusion model, using $\mathrm{NH}_{4} \mathrm{Cl}$ treated rice husk, was rather high $(0.88)$, the $C$ parameter presents a large standard deviation $(66 \%$ of the mean value), which might impair its statistical significance.

The pseudo-first and pseudo-second order models presented similar performance in the fitting of the data. The removal values $\left(q_{e}\right)$ predicted by the pseudo-first order model agrees with the equilibrium experimental data. This model considers that the occupation rate of the active sites is proportional to the number of active sites available in the adsorbent material ${ }^{35}$.

The pseudo-first-order model also showed a better fitting in the biosorption of the 5G blue dye in a study using orange bagasse as a biosorbent prepared by dehydration at different temperatures. A $\mathrm{k}_{1}$ in the value of $0.32 \mathrm{~min}^{-1}$ at $\mathrm{pH} 2$ and initial concentration of $25 \mathrm{mg} \mathrm{L}^{-1}$ has been reported ${ }^{32}$. The removal of reactive blue $5 \mathrm{G}$ (RB5G) dye in solution, $72 \mathrm{mg} \mathrm{L}^{-1}$, using the drying biomass of banana pseudo stem was investigated at $\mathrm{pH} 1$ and $30{ }^{\circ} \mathrm{C}$. For the pseudo-first order model a $\mathrm{k}_{1}$ of $0.84 \mathrm{mg} \mathrm{g}^{-1}$ was obtained. This value is due to the higher concentration of dye applied in the test ${ }^{36}$.

\subsection{Equilibrium biosorption}

Figure 5 shows the quantity of adsorbed dye per unit mass of adsorbent at equilibrium conditions as a function of the concentration of the supernatant solution at equilibrium conditions, at $\mathrm{pH} 4$ and $50{ }^{\circ} \mathrm{C}$, for in natura rice husk and $\mathrm{H}_{3} \mathrm{PO}_{4}$-treated rice husk. Equilibrium analyses with $\mathrm{NH}_{4} \mathrm{Cl}-$ treated rice husk were not carried out due to the low removal of the dye. The observed result for this treatment should be at least similar to the in nature biomass. It is suggested that the ammonium ion was adsorbed by the material and thus limiting the biosorption capacity of the biomass, which would lead to low retention of the dye as verified.

The adjusted parameters for adsorption isotherms and ANOVA of regression are shown in Table 3. 

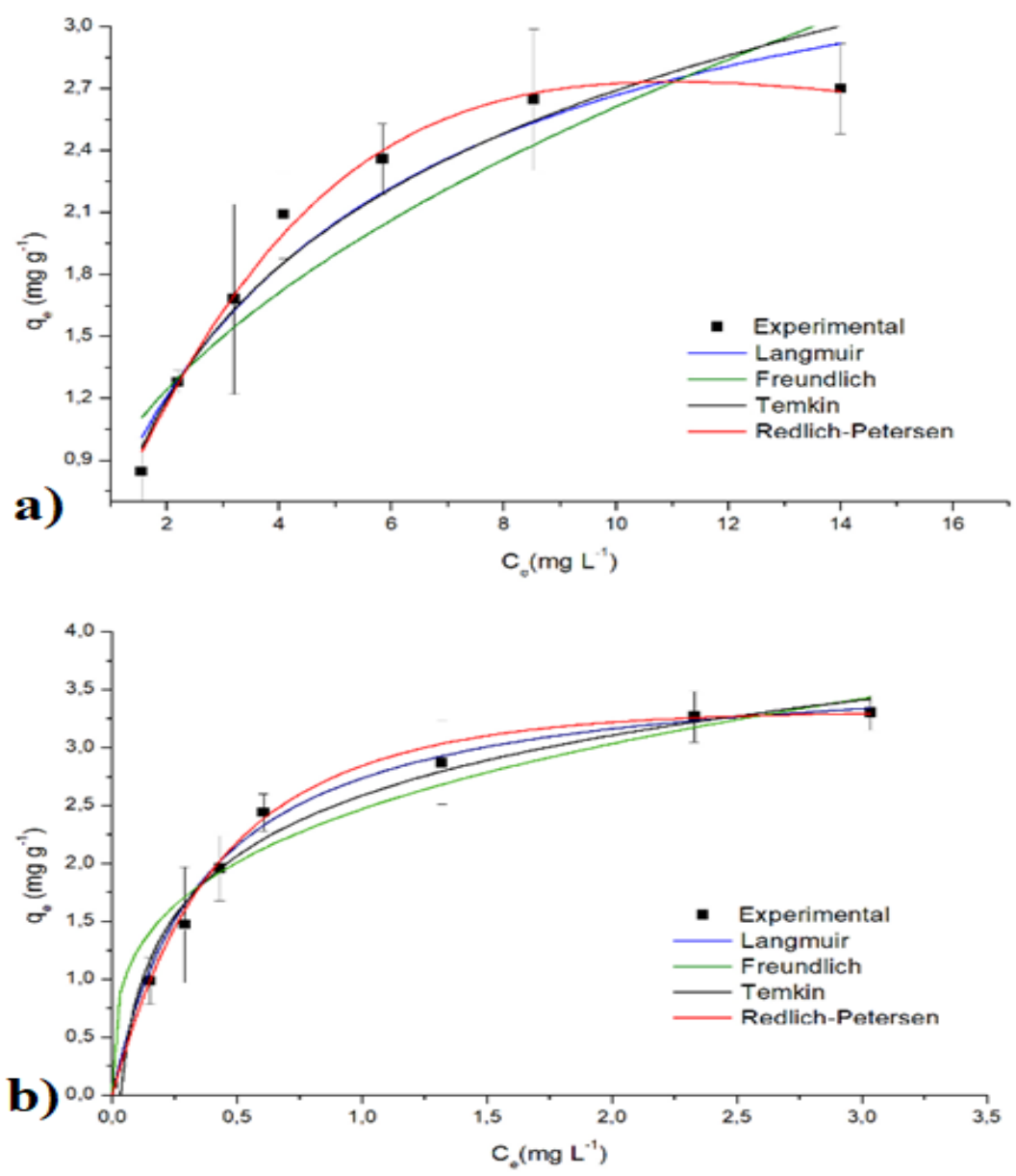

Figure 5. Experimental data and fit to Langmuir, Freundlich, Temkin and Redlich-Peterson isotherms at $50{ }^{\circ} \mathrm{C}$ and $\mathrm{pH}$ 4: a) natural and b) $\mathrm{H}_{3} \mathrm{PO}_{4}$.

Table 3. Isothermal parameters (Langmuir, Freundlich, Temkin and Redlich-Petersen) and ANOVA of regression for fitting the experimental data of biosorption of rice husk dye natural and pretreated with $\mathrm{H}_{3} \mathrm{PO}_{4}$.

Treatment

ANOVA Regression

\begin{tabular}{|c|c|c|c|c|c|c|c|}
\hline \multirow{2}{*}{ Model } & & \multirow{2}{*}{ Natural } & \multirow{2}{*}{$\mathrm{H}_{3} \mathrm{PO}_{4}$} & \multicolumn{2}{|c|}{ Natural } & \multicolumn{2}{|c|}{$\mathrm{H}_{3} \mathrm{PO}_{4}$} \\
\hline & & & & F calc & p-value & F calc & p-value \\
\hline \multirow[t]{3}{*}{ Langmuir } & $q_{m}$ & $3.74 \pm 0.09$ & $3.8 \pm 0.4$ & & & & \\
\hline & $b$ & $0.23 \pm 0.04$ & $2.7 \pm 0.3$ & 14.60 & 0.01 & 2.15 & 0.10 \\
\hline & $R^{2}$ & 0.98 & 0.95 & & & & \\
\hline \multirow{3}{*}{ Freundlich } & $k_{L}$ & $0.90 \pm 0.09$ & $2.5 \pm 0.1$ & & & & \\
\hline & $n$ & $2.2 \pm 0.3$ & $3.4 \pm 0.7$ & 3.60 & 0.10 & 2.21 & 0.10 \\
\hline & $R^{2}$ & 0.86 & 0.89 & & & & \\
\hline \multirow{3}{*}{ Temkin } & $\boldsymbol{B}$ & $0.93 \pm 0.09$ & $0.75 \pm 0.06$ & & & & \\
\hline & $k_{T}$ & $1.8 \pm 0.3$ & $32 \pm 9$ & 3.20 & 0.10 & 2.16 & 0.20 \\
\hline & $R^{2}$ & 0.95 & 0.96 & & & & \\
\hline \multirow{4}{*}{$\begin{array}{l}\text { Redlich- } \\
\text { Petersen }\end{array}$} & $k_{R}$ & $0.64 \pm 0.03$ & $8.0 \pm 0.8$ & \multirow{4}{*}{60.00} & \multirow{4}{*}{0.00} & \multirow{4}{*}{11.17} & \multirow{4}{*}{0.04} \\
\hline & $a_{R}$ & $0.03 \pm 0.01$ & $1.8 \pm 0.3$ & & & & \\
\hline & $\boldsymbol{\beta}$ & $1.6 \pm 0.1$ & $1.13 \pm 0.07$ & & & & \\
\hline & $R^{2}$ & 0.99 & 0.99 & & & & \\
\hline
\end{tabular}


Determination coefficients between 0.86 and 0.99 were observed, which means that some models do not represent the experimental data satisfactorily. The best fit was verified for the Redlich-Petersen model, being suitable for both the natural and the pre-treatment with $\mathrm{H}_{3} \mathrm{PO}_{4}$. This model predicts a heterogeneous behavior on the surface of the adsorbent. The ANOVA at the $95 \%$ significance level for the evaluation of the fit of the models to the experimental data confirmed that the Redlich-Petersen model was more adequate, since it presented $F_{\text {calc }}>F_{\text {critical }}$ for the two treatments studied (60.0 and 11.17) as well as p-value $<0.05$. It should also be noted that the Langmuir isotherm presented a favorable adjustment to the dye adsorption in the natural rice rusk, with $\mathrm{R}^{2}=0.98$ and $F_{\text {calc }}>F_{\text {critical }}$. When the constant $\beta$ of RedlichPetersen approaches 1 this equation takes the form of Langmuir. This model considers that the adsorbent has a limited number of positions on the surface. The molecules can be adsorbed to the point where all the surface sites are occupied, and adsorption will only occur in free sites, and when the equilibrium is reached no more interactions occur between the adsorbed molecules, nor between them and the medium ${ }^{37}$. The maximum adsorbed value $\left(q_{m}\right)$ of $3.81 \mathrm{mg} \mathrm{g}^{-1}$ predicted by the Langmuir model for the pretreated rice rusk corroborates the experimental values.

The application of natural and citric acid treated rice hulls was evaluated in the Direct Red 23 dye biosorption. A $q_{m}$ value was obtained for the Langmuir isotherm of 2.4 and $4.3 \mathrm{mg} \mathrm{g}^{-1}$, respectively $^{38}$. These values were like those observed for the natural husk and treated with phosphoric acid (3.7 and $3.8 \mathrm{mg} \mathrm{g}^{-1}$ ) presented in our study.

Removal of the reactive blue dye $4 \mathrm{~B}$ using natural rice husk verified that Langmuir isotherm also better fitted to or the biosorption experimental data. Thus, it can be suggested that monolayer adsorption is occurred in this study ${ }^{39}$. This also suggests that the intermolecular forces decrease rapidly with distance and consequently predicts the existence of monolayer coverage of the adsorbate at the outer surface of the adsorbent.

\section{Conclusions}

The best condition for the biosorption of the $5 \mathrm{G}$ blue reactive dye was the pretreatment with $\mathrm{H}_{3} \mathrm{PO}_{4}$ at $\mathrm{pH} 4$ and $50{ }^{\circ} \mathrm{C}$, where there was removal of $91.5 \%$. The process was favored in acidic media and elevated temperatures. The kinetic models of pseudo-first and pseudo-second order satisfactorily described the experimental data with equilibrium time of approximately $20 \mathrm{~min}$. The Langmuir and Redlich-Petersen isotherms satisfactorily described the experimental data indicating the maximum adsorbed value $\left(q_{m}\right)$ of $3.81 \mathrm{mg} \mathrm{g}^{-1}$. Thus, the results indicated that the rice husk showed a potential biosorbent for textile dye and could be used to control pollution.

\section{Acknowledgments}

The authors would like to thank UTFPR for material support.

\section{References}

[1] Giovanella, R. F., Chiarello, L. M., Barcellos, I. O., Blosfeld, A. M., Remoção da cor de soluções de corantes reativos com cinza de casca de arroz, Dynamis Revista Tecno-científica 2 (15) (2009) 1 6.

[2] Barakat, M. A., Adsorption and photodegradation of Procion yellow H-EXL dye in textile wastewater over $\mathrm{TiO}_{2}$ suspension, Journal of Hydro-environment Research. 5 (2) (2011) 137142. https://doi.org/10.1016/j.jher.2010.03.002.

[3] Kimura, I. Y., Gonçalves Jr, A. C., Stolberg, J., Laranjeira, M. C. M., Fávere, V. T. de, Efeito do pH e do tempo de contato na adsorção de corantes reativos por microesferas de quitosana, Polímeros 9 (3) (1999) 51-57. https://doi.org/10.1590/s010414281999000300010.

[4] Zouboulis, A. I., Loukidou, M. X., Matis, K. A., Biosorption of toxic metals from aqueous solutions by bacteria strains isolated from metal-polluted soils, Process Biochemistry 39 (8) (2004) 909-916. https://doi.org/10.1016/s0032-9592(03)00200-0.

[5] Castro, K. C. de, Cossolin, A. S., Reis, H. C. O. de, Morais, E. B. de, Biosorption of anionic textile dyes from aqueous solution by yeast slurry from brewery, Brazilian Archives of Biology and Technology $\quad 60 \quad$ (2017) e17160101. https://doi.org/10.1590/1678-4324-2017160101.

[6] Esposito, A., Pagnanelli, F., Lodi, A., Solisio, C., Vegliò, F., Biosorption of heavy metals by 
Sphaerotilus natans: an equilibrium study at different $\mathrm{pH}$ and biomass concentrations, Hydrometallurgy 60 (2) (2001) 129-141. https://doi.org/10.1016/s0304-386x(00)00195-x.

[7] Honorato, A. C., Machado, J. M., Celante, G., Borges, W. G. P., Dragunski, D. C., Caetano, J., Biossorção de azul de metileno utilizando resíduos agroindustriais, Revista Brasileira de Engenharia Agrícola e Ambiental 19 (7) (2015) 705-710. https://doi.org/10.1590/1807-

1929/agriambi.v19n7p705-710.

[8] Ozsoy, H., Kumbur, H., Adsorption of $\mathrm{Cu}$ (II) ions on cotton boll, Journal of Hazardous Materials 136 (3) 911-916. https://doi.org/10.1016/j.jhazmat.2006.01.035.

[9] Gimbert, F., Morin-Crini, N., Renault, F., Badot, P.-M., Crini, G., Adsorption isotherm models for dye removal by cationized starch-based material in a single component system: Error analysis, Journal of Hazardous Materials 157 (1) (2008) 34-46. https://doi.org/10.1016/j.jhazmat.2007.12.072.

[10] Liu, Y., Liu, Y.-J., Biosorption isotherms, kinetics and thermodynamics, Separation and Purification Technology, 61 (3) (2008) 229-242. https://doi.org/10.1016/j.seppur.2007.10.002.

[11] Liu, Y., Liu, Y.-J., Reply to "Comments on "Biosorption isotherms, kinetics and thermodynamics" review", Separation and Purification Technology 63 (2) (2008) 250-250. https://doi.org/10.1016/j.seppur.2008.07.006.

[12] Nascimento, P., Marim, R., Carvalho, G., Mali, S., Nanocellulose Produced from Rice Hulls and its Effect on the Properties of Biodegradable Starch Films, Materials Research 19 (1) (2016) 167-174. https://doi.org/10.1590/1980-5373-MR2015-0423.

[13] Akhtar, M., Igbal, S., Kausar, A., Bhanger, M. I., Shaheen, M. A., An economically viable method for the removal of selected divalent metal ions from aqueous solutions using activated rice husk, Colloids and Surfaces B: Biointerfaces 75 (2010) 149-155. https://doi.org/10.1016/j.colsurfb.2009.08.025.

[14] Daffalla, S. B., Mukhtar, H., Shaharun, M. S.,
Characterization of adsorbent developed from rice husk: Effect of surface functional group on phenol adsorption, Journal of Applied Sciences 10 (2010) 1060-1067.

https://doi.org/10.3923/jas.2010.1060.1067.

[15] Naiya, T. K., Bhattacharya, A. K., Mandal, S., Das, S. K., The sorption of lead (II) ions on rice husk ash, Journal of Hazardous Materials 163 (2-3) (2009)

$1254-1264$. https://doi.org/10.1016/j.jhazmat.2008.07.119.

[16] Ye, H., Zhu, Q., Du, D., Adsorptive removal of $\mathrm{Cd}$ (II) from aqueous solution using natural and modified rice husk, Bioresource Technology 101 (14) (2010) 5175-5179. https://doi.org/10.1016/j.biortech.2010.02.027.

[17] El-Shafey, E. I., Removal of Zn(II) and Hg(II) from aqueous solution on a carbonaceous sorbent chemically prepared from rice husk, Journal of Hazardous Materials 175 (1-3) (2010) 319-327. https://doi.org/10.1016/j.jhazmat.2009.10.006.

[18] Akhtar, M., Bhanger, M. I., Iqbal, S., Hasany, S. M., Sorption potential of rice husk for the removal of 2,4-dichlorophenol from aqueous solutions: Kinetic and thermodynamic investigations, Journal of Hazardous Materials 128 (1) (2006) 44-52. https://doi.org/10.1016/j.jhazmat.2005.07.025.

[19] Goel, J., Kadirvelu, K., Rajagopal, C., Garg, V. K., Removal of lead (II) by adsorption using treated granular activated carbon: batch and column studies, Journal of Hazardous Materials $125 \quad$ (1-3) (2005) 211-220. https://doi.org/10.1016/j.jhazmat.2005.05.032.

[20] Vadivelan, V., Kumar, K. V., Equilibrium, kinetics, mechanism, and process design for the sorption of methylene blue onto rice husk, Journal of Colloid and Interface Science 286 (2005) 90100. https://doi.org/10.1016/j.jcis.2005.01.007.

[21] Sumanjit, N. P., Adsorption of dyes on rice husk ash, Indian Journal of Chemistry Sec A 40 (2001) 388-391.

[22] Kosmulski, M., pH-dependent surface charging and points of zero charge II. Update, Journal of Colloid and Interface Science 275 (1) (2004)

214-224. 
https://doi.org/10.1016/j.jcis.2004.02.029.

[23] Lagergren, S., Zur theorie der sogenannten adsorption geloster stoffe, Kungliga Svenska Vetenskapsakademiens Handlingar 24 (4) (1898) 1-38.

[24] Ho, Y. S., McKay, G., Pseudo-second order model for sorption processes, Process Biochemistry $34 \quad$ (5) (1999) 451-465. https://doi.org/10.1016/s0032-9592(98)00112-5.

[25] Yang, X., Al-Duri, B., Kinetic modeling of liquid-phase adsorption of reactive dyes on activated carbon, Journal of Colloid and Interface Science $287 \quad$ (1) (2005) 25-34. https://doi.org/10.1016/j.jcis.2005.01.093.

[26] Radhika, M., Palanivelu, K., Adsorptive removal of chlorophenols from aqueous solution by low cost adsorbent-Kinetics and isotherm analysis, Journal of Hazardous Materials 138 (1) (2006) 116-124. https://doi.org/10.1016/j.jhazmat.2006.05.045.

[27] Amuda, O. S., Giwa, A. A., Bello, I. A., Removal of heavy metal from industrial wastewater using modified activated coconut shell carbon, Biochemical Engineering Journal 36 (2) (2007) 174-181. https://doi.org/10.1016/j.bej.2007.02.013.

[28] Desta, M. B., Batch Sorption Experiments: Langmuir and Freundlich Isotherm Studies for the Adsorption of Textile Metal Ions onto Teff Straw (Eragrostis tef) Agricultural Waste, Journal of $\begin{array}{llll}\text { Thermodynamics } & 2013 \quad \text { (2013) } & \text { 1-6. }\end{array}$ https://doi.org/10.1155/2013/375830.

[29] Ng, C., Losso, J. N., Marshall, W. E., Rao, R. M., Freundlich adsorption isotherms of agricultural by-product-based powdered activated carbons in a geosmin-water system, Bioresource Technology $85 \quad$ (2) (2002) 131-135. https://doi.org/10.1016/s0960-8524(02)00093-7.

[30] Gupta, V. K., Pathania, D., Singh, P., Kumar, A., Rathore, B. S., Adsorptional removal of methylene blue by guar gum-cerium (IV) tungstate hybrid cationic exchanger, Carbohydrate Polymers 101 (2014) 684-691. https://doi.org/10.1016/j.carbpol.2013.09.092.
[31] Hameed, B. H., Mahmoud, D. K., Ahmad, A. L., Equilibrium modeling and kinetic studies on the adsorption of basic dye by a low-cost adsorbent: Coconut (Cocos nucifera) bunch waste, Journal of Hazardous Materials 158 (1) (2008) 65-72. https://doi.org/10.1016/j.jhazmat.2008.01.034.

[32] Fiorentin, L. D., Trigueros, D. E., Módenes, A. N., Espinoza-Quiñones, F. R., Pereira, N. C., Barros, S. T., Santos, O. A., Biosorption of reactive blue $5 \mathrm{G}$ dye onto drying orange bagasse in batch system: Kinetic and equilibrium modeling, Chemical Engineering Journal 163 (1) (2010) 6877. https://doi.org/10.1016/j.cej.2010.07.043.

[33] Fagundes-Klen, M. R., Cervelin, P. C., Veit, M. T., da Cunha Gonçalves, G., Bergamasco, R., da Silva, F. V., Adsorption Kinetics of Blue 5G Dye from Aqueous Solution on Dead Floating Aquatic Macrophyte: Effect of pH, Temperature, and Pretreatment, Water, Air, \& Soil Pollution 223 (7) (2012) 4369-4381. https://doi.org/10.1007/s11270-012-1201-x.

[34] Saeed, A., Sharif, M., Iqbal, M., Application potential of grapefruit peel as dye sorbent: Kinetics, equilibrium and mechanism of crystal violet adsorption, Journal of Hazardous Materials $179 \quad(1-3) \quad$ (2010) 564-572. https://doi.org/10.1016/j.jhazmat.2010.03.041.

[35] Aksu, Z., Equilibrium and kinetic modelling of cadmium(II) biosorption by C. vulgaris in a batch system: effect of temperature, Separation and Purification Technology 21 (3) (2001) 285-294. https://doi.org/10.1016/s1383-5866(00)00212-4.

[36] Módenes, A. N., Espinoza-Quiñones, F. R., Geraldi, C. A. Q., Manenti, D. R., Trigueros, D. E. G., Oliveira, A. P. da, Borba, C. E., Kroumov, A. D., Assessment of the banana pseudostem as a lowcost biosorbent for the removal of reactive blue $5 \mathrm{G}$ dye, Environmental Technology 36 (22) (2015) 2892-2902.

https://doi.org/10.1080/09593330.2015.1051591.

[37] Sodré, F. F., Lenzi, E., Costa, A. C. S. da, Utilização de modelos físico-químicos de adsorção no estudo do comportamento do cobre em solos argilosos, Química Nova 24 (3) (2001) 324-330. https://doi.org/10.1590/s010040422001000300008. 
[38] Abdelwahab, O., El-Nemr, A., El-Sikaily, A., Khaled, A., Use of rice husk for adsorption of direct dyes from aqueous solution: A case study of direct F. Scarlet, Egyptian Journal of Aquatic Research 31 (1) (2005) 1-11.

[39] Chowdhury, S., Saha, T. K., Removal of reactive blue 4 (RB4) onto puffed rice in aqueous solution, International Journal of Advanced Research (IJAR) 4 (3) (2016) 927-934. 